\title{
Erratum: Clinical skills development in student-run free clinic volunteers: a multi-trait, multi-measure study
}

\author{
Mio Nakamura ${ }^{1 *}$, David Altshuler ${ }^{1}$, Margit Chadwell ${ }^{2}$ and Juliann Binienda ${ }^{2}$
}

\section{Erratum}

After publication of this work [1], we noted that we inadvertently failed to include the complete list of all coauthors. The full list of authors and the corrected Authors Contributions section are reported below. We apologize for any inconvenience this oversight may have caused.

\section{Corrected authors' list}

Mio Nakamura ${ }^{1 *}$, David Altshuler ${ }^{1}$, Margit Chadwell ${ }^{2}$, Juliann Binienda ${ }^{2}$.

\section{Corrected authors' contributions}

MN made substantial contributions to conception and design, acquisition of data, analysis and interpretation of data, and drafted the manuscript. DA made substantial contributions to conception and design, acquisition of data, analysis and interpretation of data. MC made substantial contributions to the inception of the study, revision of the manuscript, and is Medical Director of the student-run free clinic. JB made substantial contributions to conception and design, analysis and interpretation of data, and revised the manuscript. All authors read and approved the final manuscript.

\section{Author details \\ 'Wayne State University School of Medicine, Detroit 48201MI, USA. \\ 2Department of Family Medicine and Public Health Sciences, Wayne State \\ University School of Medicine, Detroit 48201MI, USA.}

Received: 12 June 2015 Accepted: 12 June 2015

Published online: 03 July 2015

\section{References}

1. Nakamura M, Altshuler D, Binienda J. Clinical skills development in student-run free clinic volunteers: a multi-trait, multi-measure study. BMC Medical Education. 2014;14:250.

\footnotetext{
* Correspondence: mnakamur@med.wayne.edu

'Wayne State University School of Medicine, Detroit 48201MI, USA

Full list of author information is available at the end of the article

\section{Submit your next manuscript to BioMed Central and take full advantage of:}

- Convenient online submission

- Thorough peer review

- No space constraints or color figure charges

- Immediate publication on acceptance

- Inclusion in PubMed, CAS, Scopus and Google Scholar

- Research which is freely available for redistribution 